\title{
PERKEMBANGAN MONETER, PERBANKAN DAN SISTEM PEMBAYARAN TRIWULAN II - 2003
}

\section{Tim Penulis Laporan triwulan II - 2003, Bank Indonesia}

Kegiatan ekonomi dalam triwulan II-2003 terus menunjukkan peningkatan. Pertumbuhan ekonomi diperkirakan mencapai 3,56\% meningkat dibanding triwulan sebelumnya yang mencapai 3,43\%. Dari sisi permintaan domestik, meskipun konsumsi pemerintah dan swasta masih merupakan pendorong utama pertumbuhan, kegiatan investasi, ekspor dan impor juga memberikan kontribusi penting terhadap pertumbuhan ekonomi.

Tingkat inflasi terus menunjukkan penurunan dan mengarah pada angka yang lebih rendah dari yang diperkirakan sebelumnya. Sampai dengan triwulan II-2003, inflasi secara tahunan mencapai 6,62\%. Rendahnya laju inflasi terutama disebabkan oleh membaiknya ekspektasi inflasi dan penguatan nilai tukar rupiah. Nilai tukar rupiah cenderung menguat secara persisten. Besarnya arus dana masuk (capital inflows) menjadi faktor utama penguatan nilai tukar rupiah sehingga pasokan valas di pasar domestik cukup tersedia. Berlanjutnya capital inflows menunjukkan bahwa penanaman dalam aset-aset rupiah masih cukup menarik bagi investor asing.

Stabilnya nilai tukar rupiah dan penurunan laju inflasi telah memberi peluang bagi berlanjutnya penurunan suku bunga instrumen moneter secara bertahap. Penurunan suku bunga SBI tersebut telah membantu mengurangi beban anggaran pemerintah, mendorong perkembangan obligasi korporasi, dan membantu restrukturisasi utang korporasi. Searah dengan penurunan tersebut, suku bunga Fasilitas Simpanan Bank Indonesia (FASBI), suku bunga pasar uang baik rupiah maupun valas, suku bunga deposito rata-rata tertimbang 1 dan 3 bulan juga menunjukkan penurunan.

Didukung oleh kondisi stabilitas ekonomi yang semakin membaik, kinerja perbankan nasional sampai dengan akhir triwulan II-2003 mengindikasikan beberapa perbaikan yang ditunjukkan dari pertumbuhan jumlah aktiva, dana pihak ketiga (DPK), penyaluran kredit, dan tingkat keuntungan. Fungsi intermediasi perbankan dalam triwulan II-2003 menunjukkan sedikit perbaikan dibandingkan triwulan sebelumnya yang ditunjukkan dari peningkatan DPK maupun penyaluran kredit. 
Melihat berbagai perkembangan tersebut, kinerja ekonomi ke depan diperkirakan akan semakin membaik. Prospek pertumbuhan ekonomi dalam triwulan III dan IV-2003 akan tetap meningkat sehingga secara keseluruhan tahun 2003 mencapai batas atas kisaran perkiraan awal tahun sekitar 3,5\%-4,0\%. Dalam paruh kedua tahun 2003, nilai tukar rupiah diperkirakan masih cenderung menguat. Inflasi dalam triwulan III-2003 diperkirakan akan tetap rendah dan sampai dengan akhir tahun 2003 diperkirakan akan mencapai 6,5\%-7,0\% atau berada di bawah target yang ditetapkan pada awal tahun. Namun demikian, dalam triwulan mendatang masih terdapat berbagai tantangan akan masih dihadapi oleh perekonomian Indonesia. Di sektor eksternal, kemungkinan membaiknya perekonomian negara maju dan kebijakan suku bunga internasional dikhawatirkan akan menarik kembali dana yang saat ini berputar di negara emerging, termasuk Indonesia. Pertumbuhan ekonomi diperkirakan terus meningkat, tetapi dibayangi oleh indikasi peningkatan tekanan hargaharga pada tahun 2004. Di sisi moneter dan perbankan, tantangan yang dihadapi terkait dengan belum cukup optimalnya fungsi intermediasi perbankan. Sementara itu, perkembangan nilai tukar tetap harus dicermati secara baik terutama akibat kemungkinan besarnya aliran keluar modal jangka panjang.

Ke depan, kebijakan moneter tetap diarahkan untuk menurunkan laju inflasi secara bertahap dalam jangka menengah panjang. Terkait dengan hal tersebut, ruang bagi penurunan suku bunga masih terbuka, dimana upaya penurunan suku bunga SBI harus dilakukan secara sangat hati-hati. Sementara itu, kebijakan perbankan tetap diarahkan pada langkah-langkah terus memperkokoh kondisi perbankan nasional dalam kerangka program restrukturisasi perbankan agar fungsi intermediasi perbankan dapat semakin meningkat.

Laporan triwulan II-2003 ini mencakup evaluasi pelaksanaan tugas dan wewenang Bank Indonesia di bidang moneter, perbankan, dan sistem pembayaran dengan penekanan pada evaluasi pencapaian sasaran inflasi dan sasaran moneter lainnya. Sistematika penyajian laporan terbagi dalam beberapa bab. Bab 2 memaparkan evaluasi Bank Indonesia atas perkembangan kinerja makroekonomi dan kinerja inflasi. Selanjutnya bab 3, 4, 5 masingmasing memaparkan evaluasi atas kebijakan dan perkembangan di bidang moneter, perbankan, dan sistem pembayaran. Bab 6 mengemukakan pandangan Bank Indonesia mengenai prospek ekonomi dan arah kebijakan mendatang termasuk permasalahan yang dihadapi perekonomian dan berbagai langkah yang akan ditempuh Bank Indonesia untuk mengatasinya. Dalam lampiran laporan ini juga disampaikan evaluasi kebijakan di bidang manajemen intern serta produk-produk hukum Bank Indonesia selama triwulan laporan. Secara keseluruhan, rangkuman dari materi laporan triwulan II-2003 disajikan dalam Tinjauan Umum ini. 


\section{EVALUASI PERKEMBANGAN INFLASI DAN MAKROEKONOMI}

\subsection{Kinerja Inflasi dan Nilai Tukar}

Perkembangan inflasi selama triwulan II-2003 mencapai 0,45\% (q-t-q), lebih rendah dari inflasi pada triwulan I-2003 yang mencapai 0,77\% (q-t-q). Sejalan dengan itu, laju inflasi tahunan menunjukkan trend menurun. Sampai dengan triwulan laporan tercatat $6,62 \%$, lebih rendah dari triwulan I-2003 yang mencapai 7,12\%. Laju inflasi tersebut jauh lebih rendah dari perkiraan semula yaitu $9,38 \%$. Rendahnya laju inflasi tersebut terutama didorong oleh melimpahnya pasokan (positive supply shock) bahan makanan. Ekspektasi inflasi yang cenderung membaik, dan perkembangan nilai tukar yang cenderung menguat.

Sepanjang triwulan II-2003, nilai tukar rupiah menunjukkan kecenderungan menguat. Secara rata-rata rupiah menguat 4,88\% menjadi Rp8.488 per dolar AS, sementara secara point to point rupiah menguat lebih tajam $(7,58 \%)$ ke posisi Rp 8.275 per dolar AS. Derasnya capital inflows menjadi faktor utama penguatan nilai tukar rupiah sehingga meningkatkan pasokan valas di pasar domestik. Perkembangan tersebut sejalan dengan data neraca pembayaran Indonesia (NPI) yang diperkirakan mencatat surplus sebesar USD2.162 juta dalam triwulan II 2003, meningkat tajam dari surplus USD541 juta dalam triwulan sebelumnya. Berlanjutnya capital inflows menunjukkan bahwa penanaman dalam aset-aset rupiah semakin menarik bagi investor asing.

Beberapa faktor lainnya yang menopang daya tarik rupiah antara lain membaiknya indikator risiko, suku bunga dalam yang jauh lebih besar dari suku bunga luar negeri dan semakin beragamnya outlet penanaman dalam rupiah. Penguatan rupiah secara nominal menyebabkan nilai tukar rupiah secara riil juga menguat (angka-angka indeks REER dan BRER) sehingga mendukung penurunan laju inflasi. Namun di sisi lain, penguatan rupiah juga dapat mengganggu daya saing ekspor, bila berbagai faktor lain termasuk efisiensi dan produktivitas nasional tidak diperbaiki.

\subsection{Kinerja Makroekonomi}

Seiring dengan optimisme ekonomi global, ekonomi Indonesia mencatat surplus neraca pembayaran. Dalam hal ini neraca modal memberikan kontribusi yang berarti yaitu mencatat peningkatan surplus akibat terjadinya capital inflows. Membaiknya pertumbuhan ekonomi Indonesia yang selaras dengan mambaiknya indikator-indikator makroekonomi dan moneter, ditambah dengan rendahnya suku bunga internasional relatif terhadap suku bunga domestik menyebabkan meningkatnya capital inflow ke Indonesia. Di sisi neraca transaksi berjalan, terjadi penurunan surplus yang cukup berarti yang disebabkan peningkatan impor lebih tinggi dibandingkan dengan peningkatan ekspor. 
Dari sisi permintaan, PDB pada triwulan II-2003 yang diprakirakan mencapai 3,56\% (y.o.y), sedikit lebih tinggi dibandingkan triwulan sebelumnya sebesar 3,43\% (y.o.y). Pertumbuhan yang lebih tinggi tersebut disebabkan juga oleh kenaikan komponen investasi dan konsumsi swasta. Investasi pada triwulan diprakirakan meningkat yang diindikasikan dengan meningkatnya PMA sepanjang Januari-Mei 2003 dibandingkan periode yang sama tahun sebelumnya, meningkatnya emisi obligasi korporasi yang diterbitkan pada triwulan laporan, dan peningkatan investasi pemerintah. Sementara itu, konsumsi yang merupakan penyumbang terbesar PDB juga cenderung meningkat sejak awal tahun yang tercermin dari hasil survei konsumen dan penjualan eceran. Konsumsi pemerintah pada triwulan laporan juga diprakirakan meningkat dibandingkan triwulan yang sama tahun sebelumnya.

Sementara itu di sisi sektoral, kegiatan ekonomi pada triwulan II-2003 didukung oleh pertumbuhan positif yang terjadi di seluruh sektor pembentuk PDB, dengan sumbangan

Tabel 1.1. Indikator Makroekonomi

\begin{tabular}{|c|c|c|c|c|c|c|}
\hline \multirow{2}{*}{ Indikator } & \multicolumn{4}{|c|}{2002} & \multicolumn{2}{|c|}{2003} \\
\hline & Trw I & Trw II & Trw III & Trw IV & Trw I & Trw II \\
\hline \multicolumn{7}{|l|}{ IHK(\%) } \\
\hline Triwulanan (quarter to quarter) & 3,50 & 0,92 & 1,65 & 3,63 & 0,77 & 0,46 \\
\hline Tahunan (yearon year) & 14,08 & 11,48 & 10,48 & 10,03 & 7,12 & 6,62 \\
\hline PDB (\% pertumbuhan,tahunan) & 2,7 & 3,9 & 4,3 & 3,8 & $3,4^{*}$ & $3,6^{*}$ \\
\hline \multicolumn{7}{|l|}{ Darisisipermintaan: } \\
\hline KonsumsiTotal & 5,7 & 5,3 & 5,2 & 5,9 & $4,5^{*}$ & $4,8^{*}$ \\
\hline InvestasiTotal & $-8,9$ & $-4,6$ & 4,6 & 8,9 & $6.4^{*}$ & $6.9^{*}$ \\
\hline \multicolumn{7}{|l|}{ Darisisi produksi: } \\
\hline Pertanian & $-3,1$ & 3,9 & 3,8 & 2,4 & $3,2^{*}$ & $1,6^{*}$ \\
\hline Pertambangan & $-1,5$ & 2,2 & 2,7 & 5,7 & $1,4^{*}$ & $0,5^{*}$ \\
\hline IndustriPengolahan & 5,6 & 3,9 & 4,2 & 2,4 & $2,7^{*}$ & $3,0^{*}$ \\
\hline \multicolumn{7}{|l|}{ Sektoreksternal: } \\
\hline Ekspornonmigas(fob, \% pertumbuhantahunan) & $-8,2$ & $-2,9$ & 11,4 & 4,3 & $5,0^{*}$ & $14,9^{*}$ \\
\hline Impornonmigas(c\&f, \% pertumbuhantahunan) & $-9,9$ & $-3,8$ & 20,2 & $-2,1$ & $6,4^{*}$ & $11,0^{*}$ \\
\hline Transaksiberjalan(jutaUSD) & 1.650 & 1.894 & 2.427 & $1.291^{*}$ & $1.568^{*}$ & $779 * *$ \\
\hline PosisiUtangLN(jutaUSD) & 131.556 & 132.136 & 131.290 & 130.897 & $130.126^{*}$ & $130.155^{* *}$ \\
\hline \multicolumn{7}{|l|}{ Besaran Moneter(miliarRP) } \\
\hline $\mathrm{M}$ & 117.016 & 119.943 & 123.869 & 138.250 & 125.211 & 132.403 \\
\hline M & 166.173 & 174.017 & 181.791 & 191.939 & 181.239 & $191.709^{* *}$ \\
\hline $\mathrm{M}$ & 831.410 & 838.635 & 859.706 & 883.908 & 877.776 & $893.039^{* *}$ \\
\hline \multicolumn{7}{|l|}{ Sukubunga $(\%)^{1)}$} \\
\hline SBI1bulan & 16,76 & 15,11 & 13,22 & 12,93 & 11,40 & 9,53 \\
\hline PUAB (overnight) & 15,41 & 14,47 & 12,86 & 12,44 & 12,70 & 6,99 \\
\hline Deposito1bulan & 15,64 & 14,76 & 13,50 & 12,81 & 11,90 & $11,02^{* *}$ \\
\hline Kreditmodalkerja & 19,35 & 19,08 & 18,74 & 18,25 & 18,08 & $17,75^{* *}$ \\
\hline Kreditinvestasi & 18,03 & 18,11 & 18,11 & 17,82 & 17,85 & $17,67^{* *}$ \\
\hline Kurs(Rp/USD),nominalakhirperiode & 9.825 & 8.713 & 9.000 & 8.950 & 8.693 & 8.275 \\
\hline Real Effective Exchange Rate (REER)', $1995=100$ & 82,2 & 84,8 & 84,1 & 86,1 & 87,2 & 92,6 \\
\hline Kursrata-rata & 10.188 & 8.703 & 8.951 & 9.045 & 8.902 & 8.488 \\
\hline
\end{tabular}


terbesar berasal dari sektor industri pengolahan, sektor perdagangan dan sektor pengangkutan. Pertumbuhan sektor industri pengolahan ini tercermin antara lain dari kecenderungan peningkatan indeks produksi. Sementara di sektor perdagangan, hotel dan restauran, pertumbuhannya terutama disumbang oleh pertumbuhan sub sektor perdagangan seperti ditunjukkan oleh hasil survei penjualan eceran yang menunjukkan adanya tren peningkatan indeks penjualan eceran.

\section{EVALUASI KEBIJAKAN DAN PERKEMBANGAN MONETER}

Pada triwulan II-2003 berbagai indikator moneter dan keuangan terus menunjukkan perkembangan yang membaik dan terkendali. Perkembangan uang primer terus menunjukkan pergerakan yang stabil dan terkendali, sehingga berada di bawah level indikatif targetnya. Trend penguatan nilai tukar rupiah dan penurunan inflasi juga terus berlangsung, sehingga masih memberikan ruang gerak bagi Bank Indonesia untuk menurunkan suku bunga guna memberikan peluang bagi perbankan untuk menurunkan suku bunga kredit dan meningkatkan fungsi intermediasinya serta memberikan peluang pembiayaan yang lebih efisien kepada sektor riil.

Sementara itu, trend penurunan suku bunga SBI berlanjut dengan akselerasi cepat dan diikuti oleh suku bunga FASBI, PUAB, dan deposito. Namun demikian, suku bunga kredit perbankan belum merespon secara proporsional penurunan suku bunga instrumen moneter karena terkendala oleh pemenuhan target profitabilitas dan faktor risiko. Penurunan suku bunga instrumen moneter juga berdampak pada membaiknya fungsi intermediasi perbankan yang trecermin pada meningkatnya pertumbuhan kredit. Sementara itu, fenomena lain yang berkembang yaitu penurunan suku bunga instrumen moneter juga mendorong jalur transmisi moneter melalui pasar modal untuk pembiayaan sektor riil melalui penerbitan obligasi korporasi.

Pada triwulan II-2003 berbagai indikator moneter dan keuangan terus menunjukkan perkembangan yang membaik. Uang primer pada akhir triwulan II-2003 turun 13,04\% (q-tq) dari posisi akhir triwulan sebelumnya. Sementara itu, rata-rata pertumbuhan tahunan test date uang primer pada triwulan II-2003 tercatat sebesar 6,38\%, lebih rendah dari triwulan sebelumnya sebesar $8,46 \%$ dan triwulan I-2002 sebesar 13,23\%. Turunnya posisi dan melambatnya pertumbuhan uang primer pada triwulan II-2003 ini sesuai dengan pola musimannya yang terutama disebabkan oleh menurunnya permintaan uang kartal.

Sejalan dengan stabilnya nilai tukar rupiah dan penurunan laju inflasi, kecenderungan penurunan suku bunga SBI masih terus berlanjut, bahkan dalam lelang di akhir triwulan II2003 (25 Juni 2003) telah mencapai 9,53\%. Trend penurunan suku bunga instrumen moneter tersebut telah berdampak langsung pada suku bunga dana, namun belum sepenuhnya 
berpengaruh terhadap suku bunga kredit perbankan terkendala dengan pemenuhan target keuntungan bank. Penurunan suku bunga SBI dan Fasilitas Simpanan Bank Indonesia (FASBI) yang terjadi direspon secara bervariasi oleh suku bunga perbankan. Searah dengan perkembangan suku bunga instrumen moneter, suku bunga pasar uang antar bank (PUAB) baik rupiah dan valas menunjukkan penurunan. PUAB over night pagi dan sore turun masing-masing sebesar 181 bps dan 411 bps menjadi 9,71\%. Penurunan suku bunga ini sejalan dengan besarnya likuiditas di pasar uang dan terbatasnya penempatan instrumen pasar uang.

Penurunan suku bunga instrumen moneter juga ditransmisikan terhadap suku bunga simpanan. Suku bunga deposito RRT 1 dan 3 bulan mengalami penurunan walaupun dengan akselerasi yang tidak cepat yaitu sebesar 88 bps dan 42 bps. Relatif stabilnya penurunan suku bunga deposito tersebut terkait dengan upaya bank untuk mempertahankan deposannya. Sementara itu, suku bunga kredit belum menurun secara proporsional karena adanya kendala pemenuhan target tingkat keuntungan bank dan faktor risiko. Suku bunga kredit perbankan dalam 2 bulan terakhir menunjukkan penurunan sebesar 33 bps untuk kredit modal kerja, 24 bps untuk kredit konsumsi, dan 18 untuk kredit investasi. Sementara itu, penurunan suku bunga instrumen moneter telah mendorong munculnya fenomena dalam sektor keuangan. Penurunan suku bunga instrumen moneter telah mendorong berkembangnya obligasi korporasi, disamping mempermudah restrukturisasi pinjaman korporasi. Hal ini menunjukkan bahwa korporasi mulai tidak lagi bergantung semata pada perbankan dalam membiayai kegiatan usahanya.

\section{EVALUASI KEBIJAKAN DAN PERKEMBANGAN PERBANKAN}

Dalam triwulan II-2003 kebijakan Bank Indonesia di bidang perbankan tetap difokuskan pada berbagai langkah untuk memperkokoh kondisi perbankan nasional sebagai kesinambungan program restrukturisasi perbankan. Program tersebut difokuskan untuk melanjutkan upaya program penyehatan lembaga perbankan dan pemantapan ketahanan sistem perbankan antara lain melalui pengembangan infrastruktur, peningkatan good corporate governance, serta penyempurnaan pengaturan dan pemantapan sistem pengawasan bank.

Dalam kerangka penyempurnaan pengaturan, dalam triwulan II-2003 Bank Indonesia mengeluarkan beberapa ketentuan diantaranya adalah mengenai prinsip kehatihatian dalam kegiatan penyertaan modal. Ketentuan ini dimaksudkan agar bank memiliki penanaman dana dalam bentuk penyertaan yang berkualitas baik. Untuk itu, diatur mengenai persyaratan dan kriteria bank yang dapat melakukan penyertaan, antara lain rasio kecukupan modal, profil risiko, kecukupan sistem pengendalian intern, dan 
pencantuman rencana penyertaan pada rencana kerja tahunan bank. Di samping itu, ditetapkan kriteria perusahaan yang dapat menjadi tempat penyertaan yaitu bank lain, bank perkreditan rakyat, dan perusahaan lain di bidang keuangan seperti sewa guna usaha, modal ventura, perusahaan efek, asuransi, serta lembaga kliring penyelesaian dan penyimpanan.

Sementara itu, dalam triwulan II-2003 kinerja perbankan mengalami perbaikan. Di sisi penghimpunan dana, secara nominal, dana pihak ketiga (DPK) perbankan selama triwulan II-2003 mengalami peningkatan sebesar Rp0,3 triliun menjadi Rp838,1 triliun. Sementara itu, fungsi intermediasi perbankan mengalami perbaikan tercermin dari meningkatnya posisi kredit yang disalurkan oleh perbankan yaitu dari Rp833,4 triliun menjadi Rp838,1 triliun.

Kredit baru khususnya kredit konsumsi mengalami pertumbuhan yang relatif cepat. Sejak tahun 2002 bank meningkatkan pemberian kredit konsumsi sebagai salah satu strategi untuk meningkatkan return. Secara kumulatif, kredit baru selama tahun 2003 mencapai Rp34,9 triliun atau rata-rata sebesar Rp7,0 triliun per bulan. Pertumbuhan ini membaik dibandingkan dengan rata-rata pertumbuhan kredit baru pada tahun 2002 yang hanya Rp6,6 triliun per bulan. Angka pertumbuhan ini mendekati target dalam business plan bank-bank yaitu sebesar Rp7,5 triliun per bulan. Khusus pada bulan Mei 2003, kredit yang dicairkan mencapai Rp6,4 triliun, terdiri dari kredit modal kerja Rp3,9 triliun, kredit investasi Rp1,2 triliun dan kredit konsumsi Rp1,3 trlyun. Dari total pemberian kredit baru tersebut, sebesar 54,6\% merupakan kredit untuk sektor Usaha kecil dan Menengah (UKM).

Ditinjau dari risiko kredit, dalam jangka pendek risiko kredit perbankan dinilai masih moderat mengingat bahwa porsi kredit NPL dalam struktur aktiva produktif hanya berkisar $3,4 \%$ atau 3,2\% dari total asset perbankan. Dalam jangka panjang, risiko kredit perbankan masih cukup tinggi dan cenderung fluktuatif. Hal tersebut terutama disebabkan oleh masih adanya kecenderungan peningkatan NPL gross dalam semester I- 2003. NPL gross meningkat dari 8,10\% per Desember 2002 menjadi 8,30\% per Mei 2003. Sementara itu, rata-rata permodalan bank masih di atas kebutuhan minimum yang ditunjukkan oleh CAR agregat yang mencapai $23,5 \%$, sedikit menurun dibanding triwulan sebelumnya.

Industri perbankan syariah dalam periode laporan menunjukkan perkembangan yang cukup menggembirakan. Volume usaha industri perbankan syariah pada periode laporan telah mengalami peningkatan sebesar Rp349,6 miliar (7,37\%) dibandingkan posisinya pada triwulan I-2003 menjadi Rp5.088,2 miliar. Dengan demikian, pangsa perbankan syariah terhadap perbankan nasional telah meningkat sebesar $0,03 \%$ menjadi $0,46 \%$. 


\section{EVALUASI KEBIJAKAN DAN PERKEMBANGAN SISTEM PEMBAYARAN}

Secara umum, kebijakan Bank Indonesia di bidang sistem pembayaran ditempuh pada dua bidang yakni sistem pembayaran tunai dan non tunai. Dalam triwulan II-2003 kebijakan sistem pembayaran tunai mencakup tetap diarahkan pada langkah-langkah untuk melanjutkan pemenuhan kebutuhan masyarakat akan uang kartal melalui peningkatan efektivitas pengedaran uang. Kebijakan tersebut ditempuh dengan memenuhi kebutuhan kas di Kantor Bank Indonesia di seluruh Indonesia berdasarkan Rencana Distribusi Uang (RDU) yang telah ditetapkan, meningkatkan unsur pengaman pada bahan uang dan teknik cetak uang termasuk dengan menambah unsur pengaman secara kasat mata dan kasat raba dalam menerbitkan uang emisi baru pada masa yang akan datang, program kerjasama penukaran uang pecahan kecil serta upaya penanggulangan uang palsu.

Sementara untuk sistem pembayaran non tunai, kebijakan dititikberatkan pada upaya untuk mengurangi risiko pembayaran, meningkatkan efisiensi dan kualitas serta kapasitas layanan sistem pembayaran antara lain melalui implementasi Sistem Bank Indonesia-Real Time of Gross Settlement (BI-RTGS) di Kantor Bank Indonesia (KBI), upaya meningkatkan pelaksanaan tugas mengatur dan menjaga kelancaran sistem pembayaran dengan mempersiapakan ketentuan mengenai transfer dana, dan upaya untuk mengatasi kegagalan peserta kliring dalam penyelesaian kewajiban setelmen melalui penyusunan mekanisme failure to settle scheme.

Secara umum aktivitas sistem pembayaran pada triwulan II-2003 mengalami peningkataan seiring dengan meningkatnya kebutuhan masyarakat terhadap alat pembayaran baik yang bersifat tunai maupun non tunai. Dari sisi pembayaran tunai, trend penurunan suku bunga SBI dan relatif stabilnya nilai tukar rupiah memberikan dampak yang signifikan terhadap perkembangan beberapa indikator pengedaran uang.

Bank Indonesia meningkatkan penyediaan uang untuk memenuhi kenaikan kebutuhan masyarakat akan uang kartal seiring dengan meningkatnya kebutuhan masyarakat akibat persiapan liburan dan tahun ajaran baru yang jatuh pada periode akhir triwulan II-2003. Posisi Uang Yang Diedarkan (UYD) mengalami peningkatan sebesar 5,24\% yaitu dari Rp87,35\% triliun pada triwulan I-2003 menjadi Rp92,19 triliun. Dalam rangka mengantisipasi meningkatnya permintaan masyarakat, Bank Indonesia telah meningkatkan persediaan uang kartal sebesar 4,11\% dari triwulan sebelumnya menjadi Rp81,27 triliun. Jumlah persediaan uang kartal ini diperkirakan mampu memenuhi kebutuhan masyarakat selama sekitar 5 bulan ke depan. 
Aktivitas sistem pembayaran non tunai mengalami peningkatan dibandingkan dengan triwulan sebelumnya. Hal ini tercermin dari meningkatnya nominal dan jumlah transaksi BI-RTGS yang mencapai Rp4,897 triliun dengan jumlah transaksi 972.000 atau meningkat masing masing $13,4 \%$ dan 9,7\% dibandingkan dengan triwulan sebelumnya. Sementara itu dilihat dari aktivitas kliring harian, nilai rata-rata traksaksi mengalami penurunan sebesar $2,17 \%$, sedangkan jumlah nilai rata-rata nominal harian meningkat 2,45\%. Dengan demikian nominal dan jumlah rata-rata transaksi harian kliring masing-masing menjadi Rp4,5 triliun dan 293 ribu warkat pada triwulan laporan.

\section{PROSPEK EKONOMI DAN MONETER SERTA ARAH KEBIJAKAN KE DEPAN}

\subsection{Prospek Ekonomi Makro}

Prospek ekonomi pada triwulan II-2003 diperkirakan akan membaik dibandingkan dengan triwulan sebelumnya. Mencermati perkembangan indikator eksternal, permasalahan yang membayangi prospek ekonomi di paro pertama tahun 2003 seperti dampak perang Irak dan wabah SARS diprakirakan telah berangsur mereda di triwulan mendatang. Dari sisi domestik, meningkatnya kepercayaan konsumen dan membaiknya pembiayaan investasi diprakirakan akan memberikan kontribusi yang signifikan terhadap pertumbuhan ekonomi. Di samping itu, upaya Pemerintah untuk memberikan stimulus fiskal yang lebih besar baik melalui anggaran pembangunan maupun pengeluaran dana kontijensi diperkirakan masih akan berlanjut yang antara lain tercermin dari tingginya rencana pengeluaran Pemerintah dalam triwulan mendatang.

Mencermati perkembangan tersebut, pertumbuhan ekonomi Indonesia untuk keseluruhan tahun 2003 diprakirakan akan berada pada batas atas kisaran 3,5\%-4\%. Dari sisi permintaan, kecenderungan relatif tingginya kontribusi konsumsi swasta seperti triwulan-triwulan sebelumnya diiringi membaiknya kontribusi investasi diperkirakan menjadi pendorong meningkatnya pertumbuhan ekonomi pada triwulan laporan. Sementara pertumbuhan ekspor juga diperkirakan akan berangsur membaik meskipun kontribusinya diperkirakan belum signifikan. Membaiknya prospek investasi dan ekspor tersebut secara umum sejalan dengan membaiknya perkembangan situasi ekonomi global serta mulai menurunnya faktor risiko dan ketidakpastian di dalam negeri.

Secara sektoral, sampai dengan akhir tahun 2003 pertumbuhan positif diperkirakan terjadi di seluruh sektor ekonomi terutama ditopang oleh pertumbuhan yang terjadi pada sektor industri pengolahan, sektor perdagangan, hotel dan restoran serta sektor perdagangan. Pada triwulan III-2003 sektor industri pengolahan diprakirakan akan memberikan kontribusi terbesar terhadap pertumbuhan ekonomi. Sektor bangunan diperkirakan juga akan 
mengalami pertumbuhan didorong oleh maraknya aktivitas pembangunan seperti proyek pemerintah untuk pembangunan 10-12 bendungan besar di kawasan Indonesia Timur maupun pembangunan rumah sederhana sehat (RSS). Sementara itu sektor pertanian diperkirakan akan tumbuh melambat terkait dengan berlalunya masa panen raya. Namun demikian secara keseluruhan pada tahun 2003, kinerja sektor pertanian diperkirakan akan meningkat.

Kinerja Neraca Pembayaran Indonesia(NPI) diperkirakan akan mencatat surplus yang cukup signifikan pada neraca transaksi berjalan. Neraca transaksi berjalan diprakirakan mencatat surplus sebesar USD1,46 miliar terutama disebabkan oleh surplus neraca perdagangan hingga USD5,7 miliar dan turunnya defisit neraca jasa sebesar USD0,4 milliar. Sementara kinerja neraca modal diperkirakan akan mengalami defisit yaitu sebesar USD1,29 miliar. Hal ini sebagai akibat arus masuk modal luar negeri terutama di sektor swasta yang berangsur membaik tidak dapat mengimbangi besarnya rencana pembayaran utang luar negeri sektor swasta. Sementara itu, rencana pembayaran utang luar negeri sektor pemerintah di triwulan tersebut relatif sedikit berkurang. Dengan perkembangan tersebut, secara keseluruhan NPI dalam triwulan III-2003 diperkirakan masih akan mencatat surplus sebesar USD 0,17 miliar.

\subsection{Prospek Nilai Tukar dan Inflasi}

Kecenderungan penurunan inflasi dalam triwulan III-2003 diperkirakan akan berlanjut hingga diperkirakan menjadi sekitar 6,5\% (y-o-y), sementara pada akhir tahun 2003 inflasi diperkirakan tetap rendah mencapai 6,5\%-7,0\% atau berada di bawah target yang ditetapkan pada awal tahun. Penurunan inflasi di tahun 2003 terkait dengan peningkatan sisi penawaran yang dapat mengimbangi permintaan domestik. Kondisi tersebut antara lain didukung oleh peningkatan impor khususnya beras. Sementara itu dari sektor industri, tingginya investasi yang terjadi pada awal tahun 2003 diperkirakan akan meningkatkan kapasitas produksi dalam jangka lebih panjang. Penurunan tersebut juga ditopang adanya ekspektasi inflasi yang menurun.

Dalam paruh kedua tahun 2003 perkembangan nilai tukar Rupiah diprakirakan akan dipengaruhi oleh kebijakan suku bunga yang rendah di negara maju yang masih akan berlangsung sampai dengan akhir tahun 2003. Kondisi ini akan mempengaruhi perkembangan ekonomi dalam negeri. Kebijakan moneter yang diarahkan untuk memberikan sinyal penurunan suku bunga yang berhati-hati dengan memperhatikan target inflasi ke depan, diperkirakan masih memberikan ruang perbedaan suku bunga bagi para investor. 


\subsection{Arah Kebijakan Triwulan Mendatang}

Memperhatikan beberapa tantangan ekonomi ke depan, prospek ekonomi-moneter ke depan, dalam triwulan mendatang arah kebijakan Bank Indonesia di bidang moneter, perbankan, dan sistem pembayaran sebagai berikut :

Di bidang moneter, kebijakan moneter diarahkan untuk secara konsisten mencapai sasaran inflasi jangka menengah. Dalam kaitan itu, ruang bagi penurunan suku bunga lebih lanjut masih terbuka yang dilakukan secara hati-hati dengan kecepatan yang semakin melambat. Secara operasional, OPT tetap dilakukan untuk menjaga likuiditas perbankan agar tetap sesuai dengan kebutuhan perekonomian dan didukung oleh penggunaan instrumen sterilisasi dan intervensi di pasar valuta asing dalam menyerap kelebihan likuditas perbankan serta meminimalkan fluktuasi nilai tukar rupiah.

Di bidang perbankan, kebijakan di bidang perbankan tetap diarahkan pada langkah memperkokoh kondisi perbankan nasional agar fungsi intermediasi perbankan dapat semakin meningkat dengan cepat. Di samping itu, dalam rangka pengembangan infrastruktur perbankan khususnya bank syariah, Bank Indonesia akan aktif dan proaktif dalam membantu pengembangan institusional perbankan syariah. Dalam kaitan tersebut, Bank Indonesia menyambut baik setiap usaha dari berbagai pihak yang berkeinginan untuk mengembangkan dan perluasan usaha bank syariah. Terkait dengan penerapan ketentuan NPLs net maksimum $5 \%$ pada akhir Juni 2003, Bank Indonesia akan melakukan pengawasan intensif bagi bankbank yang belum mencapai target NPL net tersebut.

Di bidang sistem pembayaran tunai, kebijakan diarahkan untuk mengupayakan pemenuhan uang kartal sesuai dengan kebutuhan masyarakat melalui peningkatan efektivitas peredaran uang. Di samping itu, Bank Indonesia akan terus melanjutkan upaya penangulangan uang palsu antara lain melalui perluasan jejaring dan kerjasama dengan pihak-pihak terkait pada langkah penanggulangan uang palsu.

Di bidang sistem pembayaran non tunai, kebijakan tetap diarahkan pada upaya pengurangan risiko dan peningkatan efisiensi sistem pembayaran melalui perluasan implementasi sistem BI-RTGS, pengembangan Nota Kredit paperless dan penyusunan pengaturan Transfer Dana. 